\title{
UMM RAŠĪD LA CASAMENTERA Y ALCAHUETA: PARALELISMOS Y DIFERENCIAS CON CELESTINA
}

\section{UMM RAŠĪD THE MATCHMAKER AND PROCURESS: PARALLELS AND DIFFERENCES WITH CELESTINA.}

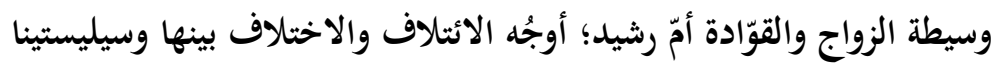

Ahmed SHAFIK*

Universidad de Oviedo

BIBLID [1133-8571] 27 (2020) 105.1-16

Resumen: El propósito de este artículo es realizar un estudio comparado entre las dos medianeras: Umm Raš̄id, heroína de la primera pieza de sombras, Țayf al-Jayāl, de Ibn Dāniyāl y la vieja Celestina de la Tragicomedia de Calisto y Melibea de Fernando de Rojas. Dos maestras del arte de la seducción, ideadas en el seno de la tradición literaria, pintura de un mundo vivo y reflejo del inmediato conocimiento que los autores tenían de su entorno social. Ante todo, el estudio aplica la crítica del modelo celestinesco para concretar la caracterización de la tercera. El cotejo sistemático de los textos revela coincidencias más que llamativas entre ambas protagonistas.

Palabras clave: Ibn Dāniyāl. Rojas. Alcahuetería. Siglos XIII-XV. Comparación. Celestina.

Abstract: The purpose of this article is to make a comparative study between the Arabic and Spanish characterization of the go-between: Umm Raš̄ìd, heroine of Ibn Dāniyāl's first shadow play, Tayf al-Khayāl and Rojas' Celestina, principal protagonist of the Tragicomedy of Calisto y Melibea. Two masters of the art of seduction, designed within the heart of literatura tradition, painting of a living world and a reflection of the immediate knowledge that the authors had of their social scene. First of all, the study applies the criticism of the Celestinesque model to concrete the characterization of the go-between. The systematic comparison of the texts reveals more clear resemblances between both protagonists.

Key words: Ibn Dāniyāl. Rojas. Matchmaking. Bawdry. XIII-XV Centuries. Comparison. Celestina.

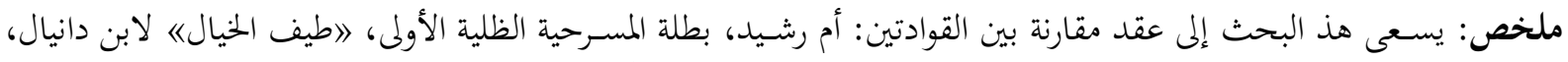

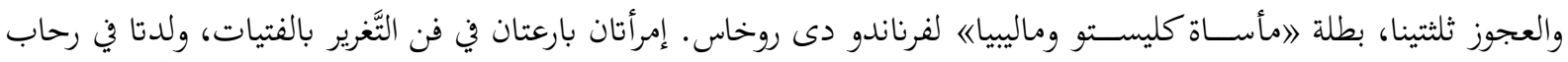

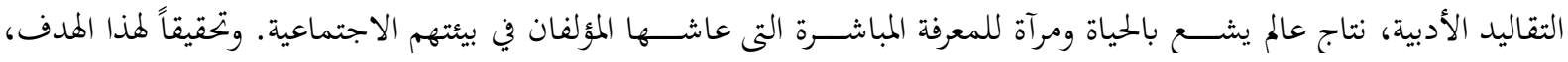

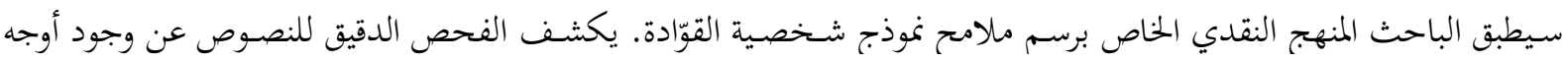

$$
\begin{aligned}
& \text { تشابه عميقة بين البطلتين. } \\
& \text { كلمات مفاتيح: ابن دانيال. روخاس. القِيادة. القرن الثالث عشر والخامس عشر . مقارنة. لاثلستينا أو القوادة. }
\end{aligned}
$$

La proyección del personaje de la alcahueta es uno de los más complejos de la tradición literaria, gracias, sobre todo, a la vieja Celestina, creada por Fernando de Rojas en suelo español. En la mayoría de las composiciones celestinescas se repiten los tópicos de la tradición, si bien la concepción de los autores no es nada homogénea. Para algunos la presencia de la alcahueta es simplemente un elemento anecdótico, y para otros, ocupa un lugar primordial en

\footnotetext{
*_E-mail: anouralhouda@hotmail.com
} 
la intervención de la trama ${ }^{(1)}$. En artículos dispersos se han señalado los antecedentes orientales de la elaboración del personaje celestinesco y su conexión con la alcahuetería tradicional poniendo el acento en la singular situación sociocultural que conoció la Península Ibérica durante la Edad Media. Incluso algunos estudiosos han intentado buscar el linaje de la alcahueta española en Umm Rašīd, una figura típicamente celestinesca del siglo XIII, del teatro de sombras del dramaturgo egipcio Ibn Dāniyāl $(\mathrm{m} .710 / 1310)^{(2)}$. No obstante, dichos trabajos no han reflejado adecuadamente los rasgos característicos de la alcahueta y su relación con su homóloga oriental por varias razones:

a) los estudiosos contaron con traducciones parciales al inglés o al alemán de la obra de Ibn Dāniyāl, cuya edición crítica aún no había visto la luz, de modo que confunden personajes (p. ej. el marido de la alcahueta con el dueño de su casa);

b) como consecuencia de esta parcialidad, la mayor parte de las referencias son esporádicas, carentes de sistematización a situaciones, motivos y ambientes (p. ej. al-hammām 'casa de baño') que dan debida cuenta de su funcionalidad en el entramado dramático;

c) caen en algunos errores, p. ej. la ascendencia judía de Ibn Dāniyāl; la despreocupación por el tema de la virginidad de la mujer en el Islam Medieval ${ }^{(3)}$.

Pese a estas carencias, algunos planteamientos nos sirven de guía respecto a la caracterización de la tercera. Quedan, en efecto, retratos y evocaciones celestinescos que completan el perfil y el protagonismo de la alcahueta oriental. Desde una perspectiva comparada, Márquez Villanueva señala:

La tradicionalidad que seguía actuando sobre Rojas incluía [...] inconfundibles elementos de procedencia oriental [...]. La tradición literaria del tipo celestinesco oriental se hallaba formada ya en la segunda mitad del siglo XIII y sus ecos estaban todavía de algún modo presentes en la vida de una ciudad castellana del siglo xv. [...] Los parámetros y líneas de avance de tal proceso no ofrecen [...] mayor dificultad, dada la conspicua presencia del tema y personaje en la cuentística y literatura de exempla, así como en la conexión de Juan Ruiz con la amplísima provincia de la erotología y libros de $a d a b^{(4)}$.

Avanzando en esta dirección crítica, sin perder de vista los rasgos compartidos de la alcahueta hispánica con sus antecedentes en la literatura latina clásica, el mismo estudioso sitúa el modelo celestinesco: «dentro de un fenómeno de orientalización de la vida cotidiana» ${ }^{(5)}$.

Tanto Ibn Dāniyāl como Fernando de Rojas acceden a la realidad a través de la palabra creativa, entendiendo el arte como proyección de la vida y recobrando el significado de la condición humana en un mundo de máscaras, disimulo o juego de sombras. Ibn Dāniyāl, buen conocedor de las distintas corrientes literarias y manuales de erotología (kutub al-bāh) y cliente asiduo de las tabernas de El Cairo, introduce la figura de la alcahueta a base de una visión realista. Como estudiante de Artes en Salamanca, Rojas tuvo que conocer una larga tradición

(1) Este trabajo es complementario al realizado por nosotros sobre el personaje de la alcahueta, véase Shafik. A, «La mujer en el teatro de Ibn Dāniyāl», Miscelánea de Estudios Árabes y Hebraicos, 67 (2018), 20125, pp. 207-16.

(2) Shafik. A, «Ibn Dāniyāl (646/1248-710/1310): poeta y renovador del teatro de sombras», Miscelánea de Estudios Árabes y Hebraicos, 61 (2012) 87-111.

(3) Datos señalados por Kotzamanidou, seguida por Lama, véase $M^{a}$. Kotzamanidou, «The Spanish and Arabic characterization of the go-between in the ligth of popular performance». Hispanic Review, 48 (1980) 91109, pp. 91, 97; de Lama, V., «Un antecedente de la Celestina a finales del siglo XIII: El teatro de sombras de Ibn Dāniyāl»», en Actas del Congreso Internacional de la Literatura en la Época de Sancho IV (21-24 de febrero de 1994). Coord. J. M. L. Mejías y C. A. Ezquerra. Madrid: Univ. de Alcalá, 1996, 399-413, pp. 408-9.

(4) Márquez Villanueva, F. Orígenes y sociología del tema celestinesco, Barcelona: Anthropos, 1993, pp. 180-1.

(5) Ibíd., p. 187. 
literaria, desde la tradición clásica de la lena 'medianera' latina, hasta el Libro de buen Amor, en que se identifica la buhonera con la alcahueta en el modelo de la Trotaconventos. Junto a formas literarias y vitales de carácter oriental, perfectamente asimiladas, Rojas debió de tener en cuenta el entorno prostibulario, situado bajo el ambiente universitario de Salamanca, como telón de fondo. Hubo, de hecho, una estrecha relación entre estudiantes y alcahuetas, bien difundida en muchas partes ${ }^{(6)}$.

En las páginas siguientes se procederá al análisis textual de las dos obras, análisis encaminado hacia la comparación de ambos personajes, resaltando una serie de peculiaridades que los definen para determinar el grado de parentesco que ha llegado a su cenit en la obra de Rojas. El enfoque comparatista es perfectamente apropiado, podemos rastrear evidentes concordancias entre Tayf al-Jayāl [Sombra de la Fantasía] de Ibn Dāniyāl y la Tragicomedia de Calisto y Melibea, más conocida como la Celestina, de Rojas, gracias a la viva imagen del tema celestinesco ${ }^{(7)}$. Entre los aspectos más destacados que vamos a estudiar, precisamos: argumento de las obras, onomástica del personaje, oficios, orgullo profesional, religiosidad y hechicería, habilidad dialéctica y arte de seducción, etc.

\section{Temática de Tayf al-Jayāl y la Celestina}

Antes de pasar al análisis de las obras, realizamos un resumen de los argumentos en orden cronológico. La trama de Tayf al-Jayāl de Ibn Dāniyāl es muy simple. Se narra la historia del emir Wișāl, un militar fanfarrón, que decide corregir una vida pervertida mediante el matrimonio. No obstante, es engañado por la alcahueta y casamentera, Umm Rašīd, que le casa con una esposa tremendamente fea. El héroe fracasa en su intento de vengarse de la alcahueta, debido a su muerte repentina. Decide viajar a La Meca para hacer la peregrinación y purificarse de sus pecados. En la obra se desarrollan escenas de barrios tradicionales de El Cairo, tabernas, palacios, equívocos, obscenidades, aventuras sexuales de todo tipo.

Respecto a la obra española, se cuenta cómo Calisto, galán enamorado, confiesa a su criado Sempronio la irrefrenable pasión amorosa que siente por Melibea. Este le aconseja solicitar la ayuda de una vieja alcahueta para la consecución de dichos amores. Calisto consigue llegar a su amada Melibea merced a la intervención de Celestina. Al negarse la alcahueta a compartir las dádivas recibidas del amante, Celestina pierde la vida de mano de sus colaboradores, Sempronio y Pármeno. Y al final, mueren igualmente los dos amantes.

A continuación, veremos cómo en ambas obras se ofrece un florecimiento cuantitativo del tipo celestinesco, donde el papel de la vieja es clave dentro de la trama. Para ello nos centramos en varias características que se revelan fundamentales en el prototipo de la alcahueta $^{(8)}$ :

(6) Ibid., pp. 119-136; Gilman, S., La España de Fernando de Rojas, Madrid: Taurus, 1978, pp. 267-345; Martín, J. L. «La ciudad y la Universidad de Salamanca en torno a 1500», en La Celestina V centenario (1499-1999), Actas del Congreso Internacional, Salamanca (27 de septiembre a 1 de octubre de 1999), ed. F. B. Pedraz Jiménez, R. G. Cañal y G. Rubio, Cuenca: Universidad de Castilla-La Mancha, 2001, pp. 49-78.

(7) Para las citas de la obra de Ibn Dāniyāl, Three Shadow Plays by Muhammad Ibn Dāniyāl. Ed. P. Kahle y D. Hopwood. Cambridge: E. J. W. Gibb Memorial Series, 1992 y para la obra de Rojas, La Celestina. Tragicomedia de Calisto y Melibea, ed. y est. F. J. Lobera, G. Serés y otros, Barcelona: Crítica, 2000. El número de página aparecerá entre corchetes en el cuerpo del texto.

(8) Sobre las características generales del modelo celestinesco, consúltense los estudios clásicos, Bataillon, $\mathrm{La}$ Célestine selon Fernando de Rojas, París: Marcel Didier, 1961, pp. 135-70; Lida de Malkiel, Ma . R., La originalidad artística de la Celestina, Buenos Aires: Eudeba, 1962, pp. 506-93; Gilman, S., La Celestina: arte y estructura, Madrid: Taurus, 1992, pp. 97-142. Véase igualmente la larga lista de estudios citada en La Celestina, p. CXCV. 


\section{Onomástica y rasgos físicos de las protagonistas}

\subsection{Onomástica y apelativos}

Nos parece necesario partir del nombre como primer ingrediente que puede proporcionar datos de interés para la caracterización del personaje: el antropónimo.

Era habitual en las obras del Medievo designar un nombre parlante, o sea, nombre que juega un papel importante en la propia pieza, gracias a su poder connotativo. Son nombres de pila y/o apellidos que proveen información específica sobre los personajes que los ostentan. La onomástica era un elemento esencial de la creación literaria, y cuando ambos autores escribieron sus obras era una tradición bien arraigada. Obsérvese ahora el juego onomástico llevado a cabo por cada autor:

\begin{tabular}{|c|c|c|}
\hline & Tayf al-Jayāl & Celestina \\
\hline Nombre & $\begin{array}{l}\text { أمّ رَشَيد Umm Rašid 'Madre de } \\
\text { Rašidd' }\end{array}$ & $\begin{array}{l}\text { Celestina (verdadero epónimo, ya que ha dado el título } \\
\text { corriente de la obra) }\end{array}$ \\
\hline $\begin{array}{ll}\text { Origen } & \mathbf{y} \\
\text { connotación }\end{array}$ & $\begin{array}{l}\text { رَشَيد significa «guía, mentor, } \\
\text { sensato, maduro», procede de رَشَ } \\
\text { «estar bien encaminado, ir por el } \\
\text { buen camino, ser sensato» }{ }^{(9)} \text {. }\end{array}$ & $\begin{array}{l}\text { Celestina se asocia al adjetivo latino caelestis, el cual } \\
\text { indica «sublime, celestial, color celeste». El nombre } \\
\text { evoca mundos puros, angélicos y celestiales. Pero } \\
\text { puede también evocar scelus 'traición, maldad'(10). }\end{array}$ \\
\hline
\end{tabular}

A primera vista, los nombres escogidos por los autores pueden referirse al uso del recurso de la antífrasis. Umm Rašīd es una vieja astuta y embaucadora, que lleva a uno de sus clientes, el emir Wișāl, a casarse con una mujer fea. Es legítimo pensar igual acerca de Celestina, protagonista principal, cuyas andanzas suelen ir acompañadas de la voz alcahueta, término despectivo y de mala reputación, a lo largo de la obra. Recordando las primeras palabras de Melibea: «... llamándome hechicera, alcahueta, vieja falsa» [150]. Lo cierto es que el engaño de Umm Rašīd viene a ser el móvil fundamental del arrepentimiento del héroe al final de la pieza de sombras. En el caso de Celestina, es una medianera profesional que ejerce su cometido sin afán de burlar a nadie. La propia alcahueta dice: «Con todos cumplo los que algo me mandan, como si toviese veinte pies y otras tantas manos» [131].

Íntimamente relacionado con el elemento onomástico es el tratamiento que otorgan los diversos personajes a Umm Rašīd y Celestina. Damos por vía de ejemplos:

\begin{tabular}{|c|c|c|}
\hline & Tayf al-Jayāl & Celestina \\
\hline $\begin{array}{l}\text { Apelativos } \\
\text { positivos }\end{array}$ & 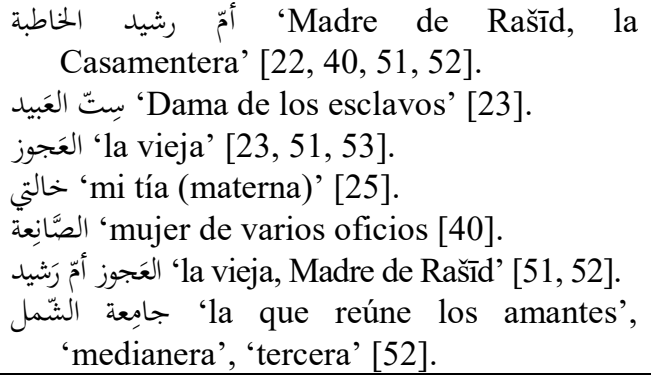 & $\begin{array}{l}\text { Calisto: Mi tía [52]; vejez virtuosa, virtud } \\
\quad \text { envejecida [...] salud de mi pasión [66]; } \\
\quad \text { señora y madre mía [143]. } \\
\text { Alisa: Vecina honrada [116]. } \\
\text { Melibea: Celestina amiga [122]. } \\
\text { Areúsa: madre, tía señora [176-77]. } \\
\text { Sempronio: madre Celestina [208]; tía señora [206]. } \\
\text { Pármeno: madre [205]. } \\
\text { Elicia: Madre [212]. }\end{array}$ \\
\hline $\begin{array}{l}\text { Apelativos } \\
\text { negativos }\end{array}$ & $\begin{array}{l}\text { أمّ رشيد القوّادة 'Madre de Rašĩd, la alcahueta' 'Mala vieja' [45]. } \\
\text { [40, 42]. }\end{array}$ & $\begin{array}{l}\text { Pármeno: Puta vieja (alcoholada) [52-53]; flaca } \\
\text { puta vieja [70]. } \\
\text { Lucrecia: vieja de la cuchillada [114]. }\end{array}$ \\
\hline
\end{tabular}

(9) Shafik, A. «Onomástica literaria y traducción: La motivación de los nombres propios en Tayf al-Jayāl 'Sombra de la Fantasía' de Ibn Dāniyāl (m. 710/1311)», en Estudios de lingüística y traductología árabe, coord. S. M. Saad, Madrid: IEEI, 2010, 151-225, pp. 197-202.

(10) Sobre el origen del nombre, La Celestina, pp. 518-19; Cherchi, P., «Onomástica celestinesca y la tragedia del saber inútil», en Cinco siglos de Celestina: Aportaciones interpretativas, ed. R. Beltrán y J. Luis Caneta, Valencia: Universitat de València, 1997, 77-90, p. 84. 


\begin{tabular}{|c|c|c|}
\hline \multirow{2}{*}{} & $\begin{array}{c}\text { Melibea: Desvergonzada barbuda... alcahueta falsa, } \\
\text { hechicera, enemiga de honestidad [126]. } \\
\text { Sempronio: lisonjera vieja; vieja llena de mal; } \\
\text { codiciosa y avarienta garganta; mala vieja } \\
\text { falsa es ésta [140]; puta alcahueta [237]. }\end{array}$ \\
\hline
\end{tabular}

En el gráfico precedente se observan unos apelativos entre sí muy distantes y opuestos. Por un lado, los respetuosos o convencionales: madre y tía, habituales en las sociedades árabes y con carácter familiar sobre todo en el gremio de la prostitución por motivos económicos y de protección; y otro, los insultantes «vieja mala» para Ibn Dāniyāl, y «puta vieja» para Rojas, rodeados por otros en guisa equivalente. La relación del emir Wiṣāl con Umm Raš̄îd pasa por dos fases. Una primera de contratación de servicios en la que el héroe y sus subordinados muestran gran respeto asociado a calificaciones afectuosas; una segunda fase tras la desaparición de la vieja, el emir la injuria con malévolos comentarios. En la obra de Rojas, el recurso de los apelativos es mucho más complicado, dependiendo del trato de la alcahueta con los demás personajes, bien los colaboradores del negocio (Sempronio y Pármeno) y sus amantes (Elicia y Areúsa), bien sus clientes (Calisto y Melibea). Los apelativos que recibe Celestina, dirigidos directamente a ella o pronunciados en apartes o en conversaciones durante su ausencia, oscilan entre adulación interesada, insultos adherentes a su profesión o afectivos por parte de las mozas ${ }^{(11)}$.

En esta línea de calificaciones, la imagen negativa de la alcahuetería trata de prevenir a los hombres contra las viejas terceras. Compárese los siguientes párrafos:

\begin{tabular}{|c|c|}
\hline Tayf al-Jayāl & Celestina \\
\hline El emir Wișāl: Habría que... sacar a la vergüenza a & Argumento: ... aviso de los engaños de las alcahuetas \\
la mala vieja en el Fusțāt, para que Satanás fuese & {$[23]^{(12)}$. } \\
amonestado y todas las viejas se arrepintiesen de & Alisa: Vieja ruin... gran traidora.... Sabe ésta con sus \\
engañar y timar a los hombres [45]. & traiciones, con sus falsas mercadurías, mudar los \\
& propósitos castos; daña la fama [230]. \\
\hline
\end{tabular}

\subsection{Rasgos físicos}

En cuanto al aspecto físico, son pocas las referencias en ambas obras. Ibn Dāniyāl saca al escenario a Umm Rašīd, casamentera y alcahueta otoñal, afligida por: «la vejez, la pesadez del cuerpo, la sordera y la debilidad de vista» [23]. La propia protagonista lamenta la decrepitud: «iQué lástima! Hoy la vejez me ha destrozado, mis cabellos han encanecido, se me han debilitado los huesos, se me han derretido la grasa y la carne por la edad» [26]. En la Tragicomedia de Rojas, se retrata una Celestina, antigua meretriz convertida por el transcurso de los años en alcahueta: «la más antigua puta vieja que fregaron sus espaldas en todos los burdeles» [67]. Una flaca anciana de cara acuchillada, barbuda y con sus «canas a cuestas» [123]. Rojas habla de su edad en dos ocasiones, «seis docenas de años» [93] en boca de Pármeno y «setenta años» [259] confesados por la propia Celestina.

De suerte que, ambas protagonistas se caracterizan por su avanzada edad. Característica dotada de dos valores: a) experiencia en el oficio; b) respeto. Por ello, tienen acceso a las casas y a la seducción de las jóvenes.

(11) De Miguel Martínez, E., «A propósito de los apelativos dirigidos a Celestina», Studia Philologica Salmanticensia, 3 (1979), 193-209.

(12) Véase igualmente La Celestina, pp. 6 y 12. 


\section{Recuerdos de la juventud}

\subsection{Lujuria}

Además de la vejez y la debilidad, sobresale un elemento caracterizador que comparten ambas heroínas. Son viejas con pasado e historia. El recuerdo nostálgico de su juventud pretérita con marcadas alusiones eróticas es un elemento común de las dos terceras. Nótese este retazo de memoria:

\begin{tabular}{|c|c|}
\hline Tayf al-Jayāl & Celestina \\
\hline 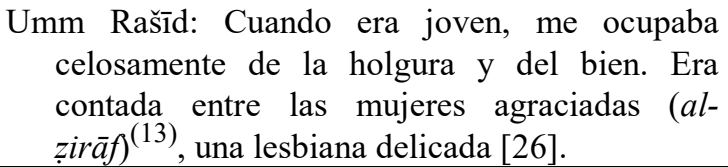 & $\begin{array}{l}\text { Celestina: [...] Parece, hija [Areúsa], que no sé yo qué cosa } \\
\text { es esto, que nunca vi estar un hombre con una mujer } \\
\text { juntos, y que jamás pasé por ello ni gocé de lo que gozas, } \\
\text { y que no sé lo que pasan y lo que dicen y hacen [182]. }\end{array}$ \\
\hline
\end{tabular}

Estas memorias arrojan luz sobre un rasgo fundamental de la alcahuetería: la lujuria. Aunque Umm Rašīd reconoce su desinterés sexual por los hombres: «Ya no siento placer ni ganas por los hombres» [26], «su vestimenta mostraba a las claras su inclinación a lo vergonzoso» [52]. Ambas protagonistas concuerdan en su erotismo lésbico. La alcahueta egipcia lo dice bien alto. En cambio, la lascivia de Celestina deja en claro su lesbianismo y voyeurismo $^{(14)}$. El autor le da el calificativo de «vieja barbuda» [47], término aplicable a las hombrunas y lujuriosas mujeres ${ }^{(15)}$. Siente fuerte pasión hacia la prostituta Areúsa: «Una enamorada tuya, aunque vieja» [173]. Su ostentación de lujuria aparece con claridad examinando el cuerpo de la ramera, prodigando una serie de piropos o viéndola retozar con Pármeno. Antes de dejar a los amantes en pleno acto sexual, Celestina palpa el vientre de Areúsa, y quizá algo más, bajo el pretexto de aplacar sus dolores, mientras pronuncia palabras sugestivas. Véanse las alusiones homoeróticas:

\begin{tabular}{|l|c|}
\hline \multicolumn{1}{|c|}{ Tayf al-Jayāl } & Celestina \\
\hline El emir Wișāl: Entre las mujeres, es delicada, & Celestina: Y qué gorda y fresca que estás! iQué \\
agraciada y dulce lesbiana [23]. & pechos y qué gentileza! [175] \\
& Celestina: [...] me hacés dentera con vuestro besar \\
& y retozar, que aún el sabor en las encías me \\
& quedó; no le perdí con las muelas [183]. \\
\hline
\end{tabular}

No es de extrañar, por tanto, que nuestros autores pongan de relieve su condición de mujeres ruines en la etapa de su juventud, mujeres que no dudan en convertir a sus maridos en cornudos. O más bien, cornudos complacientes, maridos pacientes que les sirven de tapadera o favorecen la lujuria y prostituyen a la propia mujer. Ibn Dāniyāl asemeja al marido de Umm Rašīd con los animales que llevan cuernos. Rojas, por su parte, emplea una imagen del marido cornudo propia de la época. Obsérvense estas alusiones:

(13) Según la terminología erótica, zarīfa es tríbada; véase Shafik. A, «La mujer...», p. 209.

(14) Michael Gerli, E., «El placer de la mirada: voyeurismo, fetichismo y la movilización del deseo en Celestina», en El mundo social y cultural de La Celestina. Actas del congreso internacional, Universidad de Navarra, junio, 2001, eds. I. Arellano y J. M. Usunáriz, Madrid: Vervuert, 2003, pp. 191-209.

(15) Sanz Hermida, J., «"Una vieja barbuda que se dice Celestina”: Notas acerca de la primera caracterización de Celestina», Celestinesca, 18.1 (1999), 18-33, p. 23. 


\begin{tabular}{|c|c|}
\hline Tayf al-Jayāl & Celestina \\
\hline 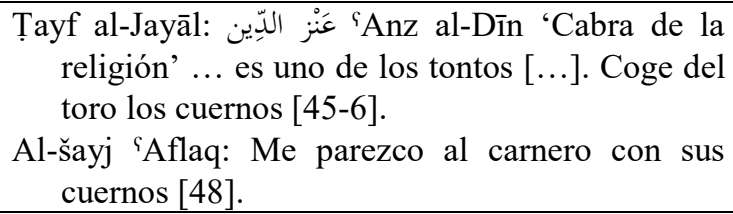 & $\begin{array}{l}\text { Pármeno: oh qué comendador de huevos asados era } \\
\quad \text { su marido } \\
\text { (16) }[54] .\end{array}$ \\
\hline
\end{tabular}

\subsection{Antiguas amistades}

Estos ejemplos del mismo corte no son los únicos que podríamos ofrecer. La similitud del pasado de ambas viejas parece más sorprendente todavía. Vecinas del mismo barrio, Umm Rāšīd entabló una amistad con la madre del emir Wișāl, y le ayudó a criar y educar de pequeño en la madraza de su marido al-šayj 'Aflaq. Además, sabe detalles y secretos de su vida, como su aventura sexual con el propietario de su casa. Un recuerdo casi parecido se encuentra en la obra de Rojas, en la que Celestina fue amiga de la madre de Pármeno, Claudina, y se encargó de cuidarlo después de la muerte de su madre. Compárense los siguientes párrafos:

\begin{tabular}{|c|c|}
\hline Tayf al-Jayāl & Celestina \\
\hline $\begin{array}{l}\text { Umm Rašīd: Ya llevamos bastante tiempo sin vernos, desde } \\
\text { la época de la casa de Qušūr, garante de las bodas en al- } \\
\text { Garbiyya. ¡Por la vida de la señora 'Ulwiyya! ¡Qué Dios } \\
\text { se apiade de su padre, su madre y su tío! Cuando Wișāl } \\
\text { tenía aquel aire de mocoso y presumido, su madre no se } \\
\text { cansaba de acicalarlo, limpiar su camino, trenzar su pelo, } \\
\text { ofrecerlo a precio de ganga. [...] Nuestro barrio es } \\
\text { pequeño, y nos conocemos todos. ¿Cómo se puede } \\
\text { olvidar, por Dios, lo ocurrido entre Wișāl y el dueño de } \\
\text { mi casa, cuando frecuentaba la madraza del šayj }{ }^{\varsigma} \text { Aflaq? } \\
\text { ¡Por Dios! ¡Qué hermoso era! ¡Qué mal es mentir! Al } \\
\text { dueño de mi casa - ¡bendito seas!- le gustaban los } \\
\text { maricones. No dejaba de darme la tabarra por este amado. } \\
\text { Hizo una fiesta con aperitivos, velas y vino [...] Le dio al } \\
\text { muchacho un buen repaso [23-5]. }\end{array}$ & $\begin{array}{l}\text { Pármeno: [...] mi madre, mujer pobre, moraba en } \\
\text { su vecindad, la cual rogada por esta Celestina } \\
\text { me dio a ella por serviente... [54]. } \\
\text { Celestina: ¡Jesú, Jesú, Jesú! ¿Y tú eres Pármeno, } \\
\text { hijo de la Claudina? [...] que tan puta vieja } \\
\text { era tu madre como yo. [...] ¿Acuérdaste } \\
\text { cuando dormías a mis pies, loquito? [...] (Tu } \\
\text { padre) envió por mí y en secreto te me } \\
\text { encargó [70-71]. } \\
\text { Aquí está Celestina que le vido nacer y le ayudó } \\
\text { a criar [100]. }\end{array}$ \\
\hline
\end{tabular}

\section{Oficios y habilidades del negocio}

Pasamos a los demás rasgos caracterizadores que tratan las distintas actividades celestinescas. Entre dichos rasgos sobresale la costumbre de la tercera de introducirse en las casas y hacerse pasar por vendedora de telas, afeites, perfumes, baratijas, galas femeninas y joyas, etc. como actividades encubridoras que le allanan el camino a la toma de contacto con las mujeres. El oficio de la alcahueta, entonces, posee una doble vertiente: un conocimiento exacto entre quienes contratan su servicio, e información errada entre sus víctimas.

\subsection{Oficios frecuentes}

De cara a la sociedad, las alcahuetas se ocupan de oficios legales. En el caso de Tayf alJayāl esta profesión legal es sobre todo la de buhonera, costurera, cosmetóloga y peinadora de novias. Y en alguna que otra ocasión, Umm Rašīd hace las veces de al-șāni $i^{\varsigma}$, mujeres habitualmente jóvenes capaces de realizar diversos oficios lícitos (venta y curación) e ilícitos (tercería $^{(17)}$. Respecto a Celestina, su actividad básica es la de labrandera, tal y como refieren Pármeno y otros personajes, cuando detallan el catálogo de sus oficios, talante y actividades. A título de ilustración, citamos estos párrafos:

(16) Según los editores, irónicamente se trataría del marido cornudo.

(17) Un estudio detallado sobre $a l-s ̦ a ̄ n i i^{\varsigma} a$, Shafik. A, «La mujer...», pp. 221-4. 


\begin{tabular}{|c|c|}
\hline Tayf al-Jayāl & Celestina \\
\hline $\begin{array}{l}\text { El emir Wișāl: Vende piezas de tejido en } \\
\text { crudo y blanqueado, y toda clase de } \\
\text { perfumes e inciensos... [23]. }\end{array}$ & $\begin{array}{l}\text { Pármeno: Ella tenía seis oficios, conviene a saber: } \\
\text { labrandera, perfumera, maestra de hacer afeites y de } \\
\text { hacer virgos, alcahueta y un poquito hechicera. Era el } \\
\text { primer oficio cobertura de los otros [54]. }\end{array}$ \\
\hline $\begin{array}{l}\text { Umm Rašìd: Me quedaba pendiente del } \\
\text { alumbramiento y la expulsión de la } \\
\text { placenta, junto al llanto doloroso del } \\
\text { recién nacido [26]. }\end{array}$ & $\begin{array}{l}\text { Pármeno: ... Y remediaba por caridad muchas huérfanas } \\
\text { y erradas que se encomendaban a ella. Y en otro } \\
\text { apartado tenía para remediar amores y para se querer } \\
\text { bien [61]. } \\
\text { Pármeno: }[\ldots] \text { hacía físico de niños [55]. }\end{array}$ \\
\hline $\begin{array}{l}\text { Umm Rašīi: Di vueltas pregonando la boda y } \\
\text { deambulé por las calles como al-șāni }{ }^{\varsigma} a \\
\text { [40]. }\end{array}$ & $\begin{array}{l}\text { Lucrecia: ... perfuma tocas, hace solimán, y otros treinta } \\
\text { oficios; conoce mucho en yerbas, cura niños, y aun } \\
\text { algunos la llaman la vieja lapidaria [115]. } \\
\text { Celestina: Vender un poco de hilado, con que tengo } \\
\text { cazadas más de treinta de su estado [148]. }\end{array}$ \\
\hline
\end{tabular}

Como queda bien reflejado en la tabla, ambas mujeres son ginecólogas y médicos de niños. En la obra de Rojas, Celestina es igualmente experta en producir virgos artificiales: «unos hacía de vejiga y otros curaba de punto» [60]. Por lo tanto, en sus hogares tienen su propio laboratorio para preparar perfumes y unturas, afrodisíacos y remedios para la impotencia sexual. Para el caso Celestina, expone elementos con supuestas propiedades mágicas. Obsérvese lo siguiente:

\begin{tabular}{|c|c|}
\hline Tayf al-Jayäl & \multicolumn{1}{|c|}{ Celestina } \\
\hline $\begin{array}{l}\text { Umm Rašìd: Preparaba los perfumes (lajälij) en } \\
\text { bujetas yemeníes y maceraba las semillas del } \\
\text { membrillo en escudillas chinas [26]. }\end{array}$ & $\begin{array}{c}\text { Pármeno: Y en su casa hacía perfumes, falsaba } \\
\text { alambiques, de redomillas... [56-61]. }\end{array}$ \\
\hline
\end{tabular}

\subsection{Espacio y tiempo de la actividad celestinesca}

La prostitución constituyó uno de los fenómenos sociales más pujantes y definidores durante la época mameluca. Dicho fenómeno fue tolerado por las autoridades a cambio de un impuesto, mientras no fuera un peligro para el bien común. Aparte de las fuentes históricas, el teatro de Ibn Dāniyāl representa un testimonio único, difícilmente encontrable en otras obras literarias $^{(18)}$. En lo que toca a la Tragicomedia de Rojas, se percibe una clase de prácticas clandestinas: prostitución privada o semi-pública del tipo realizado por Elicia o las mozas que frecuentan la casa de Celestina, carne de burdel para satisfacer los deseos de estudiantes y abades.

Ambas alcahuetas salen de su medio prostibulario para llevar su actividad celestinesca a los rincones solitarios del harén y las más íntimas moradas de la sociedad. En este contexto, hay que apuntar la índole indiscutiblemente urbana que caracteriza la figura de la alcahueta ${ }^{(19)}$. La actividad cotidiana de Umm Rašīd se desenvuelve por las calles de El Cairo, en perpetua búsqueda de clientes, víctimas e incautos. La vida de su análoga española, Celestina, es un verdadero espejo de la vida urbana - con intencionada omisión de su nombre, ciudad de la Castilla Medieval-, como la propia protagonista indica: «En esta ciudad nacida, en ella criada, manteniendo honra, como todo el mundo sabe» [99]. El ir y venir de las alcahuetas simboliza el cuadro por antonomasia del tema celestinesco. Ibn Dāniyāl se complace en presentar una imagen alegre de Umm Rašīd, «acompañada de muchachas» [53], rodeada de elementos visibles, «contoneándose con sus ajorcas ataviadas» [76] por las callejuelas donde camina, y

(18) Un estudio detallado sobre $a l-s ̦ a ̄ n i^{\varsigma} a$, Shafik. A, «La mujer...», pp. 220-21.

(19) Antonio Maravall, J., El mundo social de la Celestina, Madrid: Gredos, 1972, pp. 59-78. 
hábil con su poesía, historia y elocuencia seductora, como remedo de al-ṣāni $i^{\uparrow}$ [40]. La Celestina de Rojas es una mujer seria y diligente que camina deprisa con faldas exageradamente largas. Antes de entrar en casa de Melibea, su criada Lucrecia pregunta: «¿Quién es esta vieja que viene haldeando?» [113].

Por la senda de la misma configuración celestinesca, las protagonistas vienen definidas por el cuño particular del correr o trotar, verbos portadores de marcada connotación sexual. Esta noción erótica pasa a ser un lenguaje convenido en la alcahuetería literaria, como queda demostrado en los manuales de erotología árabe ${ }^{(20)}$. Un personaje femenino del teatro de Ibn

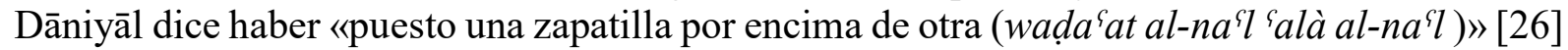
en señal de practicar el amor lésbico. Otra acepción más popular se refiere a las andanzas de las medianeras de un lugar a otro. Debido a la condición precaria de las heroínas, deben andar callejeando y gastando zapatos para ganarse la vida. Obsérvese estas alusiones:

\begin{tabular}{|c|c|}
\hline \multicolumn{1}{|c|}{ Tayf al-Jayāl } & Celestina \\
\hline $\begin{array}{l}\text { El emir Wișāl: No cambia una zapatilla vieja por } \\
\text { otra nueva [22-3]. }\end{array}$ & Celestina: Buena pro hagan las zapatas [216]. \\
\hline
\end{tabular}

La relación entre noche y alcahuetería se remonta a una antigua tradición preislámica. Los árabes solían decir a modo de proverbio: «Eres más alcahueta que la zulma o la oscuridad» ${ }^{(21)}$, puesto que:

la oscuridad o «zulma» al igual que el zurcidor o tercerón, oculta la visita del amante a su amada y les da la oportunidad de unirse sin nadie que se lo impida. Por el contrario, el alba se asemeja en ocasiones a alguien que denuncia y pone en evidencia este trato ${ }^{(22)}$.

Ambas alcahuetas pertenecen al mundo nocturno, muy oportuno para llevar a cabo sus negocios de tercería:

\begin{tabular}{|c|c|}
\hline Tayf al-Jayāl & Celestina \\
\hline $\begin{array}{l}\text { El emir Wișāl: Se parece a quien sale de noche para } \\
\text { recoger leña [22]. } \\
\text { El médico: Es ella quien reúne a los amantes en la } \\
\text { noche oscura [53]. }\end{array}$ & $\begin{array}{l}\text { Pármeno: ... en tiempo honesto, como estaciones, } \\
\text { procesiones de noche, misas de gallo, misas del } \\
\text { alba, y otras secretas devociones [55]. } \\
\text { Elicia: Andar de noche es tu placer [183]. }\end{array}$ \\
\hline
\end{tabular}

El espacio donde desarrollan sus actividades son los centros claves de la vida urbana. Aunque cada obra imprime el carácter particular de su sociedad, hay puntos en común. Por ejemplo, acudir a la casa de la tercera en busca de sus servicios; alcahuetear de casa en casa, bajo la imagen de casamentera o vendedora de perfumes e hilados; utilizar sus propios hogares como mancebías. Aparte de estas claras concordancias, hay también divergencias. En la obra egipcia, las casas de baños (al-hammāmāt) cobran relevancia, consideradas como punto de encuentro, donde las medianeras solían ejercitar sus labores de casamentería y alcahuetería. Parece ser un sitio propicio para amores lésbicos o cosecha de doncellas. En la obra de Rojas, además de la tímida mención universitaria, los templos religiosos son el centro clave de los negocios de la alcahueta. Celestina, heredera de Trotaconventos de Juan Ruiz, acudía

(20) Véase Shafik, A., «Onomástica literaria...», p. 194.

(21) Al-Tīfāšî, Nuzhat al-albāb fì mā lā yūŷad fì kitāb, ed. Ŷ. Ŷumª, Londres: Riyāḍ al-Rayyis, 1992, p. 80 (tr. esp. Esparcimiento de corazones, I. Gutiérrez de Terán, Madrid: Gredos, 2003, p. 67).

(22) Ibíd., p. 81 (tr. p. 67). 
sistemáticamente a los servicios de culto porque allí arreglaba citas amorosas. En la siguiente tabla aparecen los lugares reseñados:

\begin{tabular}{|c|c|c|}
\hline & Tayf al-Jayāl & Celestina \\
\hline 1. Casas ajenas & $\begin{array}{l}\text { El emir Wișāl: La mayor parte del } \\
\text { tiempo merodea por las casas de las } \\
\text { mujeres libres [23]. }\end{array}$ & $\begin{array}{l}\text { Pármeno: tomaba estambre de unas casas; } \\
\text { dábalo a hilar en otras, por achaque de } \\
\text { entrar en todas [55-6]. } \\
\text { Alisa: ... a tres veces que entre en una casa, } \\
\text { engendra sospecha [230]. }\end{array}$ \\
\hline 2. Baños & $\begin{array}{l}\text { El emir Wișāl: Saca de los baños a las } \\
\text { mujeres, disfrazadas con el manto de } \\
\text { las criadas [22]. }\end{array}$ & \\
\hline 3. Iglesia & & $\begin{array}{l}\text { Pármeno: Nunca pasaba sin misa ni } \\
\text { vísperas ni dejaba monasterios de } \\
\text { frailes ni de monjas, esto porque allí } \\
\text { hacía ella sus aleluyas y conciertos } \\
\text { [56]. }\end{array}$ \\
\hline 4. Universidad & & $\begin{array}{l}\text { Pármeno: Asaz era amiga de estudiantes } \\
{[55] \text {. }}\end{array}$ \\
\hline 5. Casa / burdel & $\begin{array}{l}\text { El médico: Me llamaron... para ir a una } \\
\text { casa conocida por ser un prostíbulo } \\
\text { [52]. } \\
\text { Umm Rašīd: ¿Quién me busca y } \\
\text { molesta en esta noche oscura, las } \\
\text { callejuelas están cerradas, los ojos } \\
\text { soñolientos, las estrellas dormidas y } \\
\text { cada muchacha con su amante? [23] }\end{array}$ & $\begin{array}{l}\text { Pármeno: Muchas encubiertas vi entrar en } \\
\text { su casa. Tras ellas hombres descalzos, } \\
\text { contritos, y rebozados, destacados, que } \\
\text { entraban allí a llorar sus pecados [55]. } \\
\text { Celestina: Allí [iglesia] se concertaban } \\
\text { [abades] sus venidas a mi casa [216]. } \\
\text { Celestina: A quien no me quiere no le } \\
\text { busco, de mi casa me vienen a sacar, en } \\
\text { mi casa me ruegan [259]. }\end{array}$ \\
\hline
\end{tabular}

Aparte de estos lugares, salta a la vista una observación curiosa. Ambas alcahuetas coinciden en actuar como encubridoras de mujeres recatadas. El emir Wișāl emplea el término mutanakkirāt 'disfrazadas' ( . $^{\circ} 2$ ), pero Pármeno acude al vocablo encubiertas (.$^{\circ}$ 5), que responde al sema general de cubrir o proteger, y cuyo mensaje comprende cabalmente las actividades propias de la alcahueta $^{(23)}$. O lo que es lo mismo, actuar de mediadora encubriendo o facilitando una relación amorosa, generalmente ilícita ${ }^{(24)}$.

\subsection{Profesionalidad}

Junto a esta serie de rasgos del personaje, es de indudable matriz celestinesca la profesionalidad, elemento central en ambas obras. Para el éxito de la misión de alcahuetería o casamentería, la vieja debe disponer de algunas cualidades y habilidades que inspiren confianza a sus clientes. Acudir a una vieja versada en el oficio es imprescindible. Según Celestina: «... buen acorro es una vieja conocida, amiga, madre y más que madre» [164]. Conviene dejarse guiar por su experiencia y aprovechar los recursos de los que dispone. Es interesante la similitud que existe entre los textos: a) obediencia; b) alegría por su presencia; c) clientes pobres y ricos (clérigos en la española), sanos y mutilados. Compárense:

(23) Alonso Hernández, J. L., «De Buen Amor a Celestina: estabilidad y evolución de un léxico y sus campos semánticos», Les Langues Neo-Latines, (1975) 69, 3-39, p. 17.

(24) Véase la entrada de alcahueta, Diccionario de la Real Academia Española, Espasa Calpe, Madrid, 1992, I, p. 86. 


\begin{tabular}{|c|c|}
\hline Tayf al-Jayāl & Celestina \\
\hline $\begin{array}{l}\text { Prólogo: En la alcahuetería se encuentra el secreto } \\
\text { de la obediencia y el buen augurio por la } \\
\text { apariencia del alcahuete }(a l-q u w w \bar{a} d)^{(25)} \text {, } \\
\text { porque une a los amantes y se complace en } \\
\text { caminar en la arena movediza. Es el molinero } \\
\text { que junta las dos piedras sobre el grano, al } \\
\text { modesto y al majestuoso para el amor; es quien } \\
\text { reúne a sanos y mancos para disfrutar de las } \\
\text { noches del viernes [4]. }\end{array}$ & $\begin{array}{l}\text { Celestina: Todos me obedecían, todos me } \\
\text { honraban, de todas era acatada [...], no } \\
\text { escogían más de lo que yo les mandaba: cojo o } \\
\text { tuerto o manco }[\ldots] \text {. Caballeros viejos y mozos, } \\
\text { abades de todas dignidades }[\ldots] \text { que en } \\
\text { viéndome entrar [por la iglesia] se turbaban... } \\
\text { besando el cabo de mi manto, y aun algunos en } \\
\text { la cara }[215-16] .\end{array}$ \\
\hline
\end{tabular}

En la farsa egipcia, el emir Wișāl reconoce el conocimiento profesional de la tercera en asuntos de matrimonio y alcahuetería. Mientras, en la Tragicomedia, se subraya la calaña de Celestina en su calidad de medianera en negocios carnales, mujer altamente respetada por sus cualidades y prestigio. Son maestras sabias en todos los enredos y sacaliñas del oficio. Véanse los siguientes textos:

\begin{tabular}{|r|c|}
\hline Tayf al-Jayāl & Celestina \\
\hline El emir Wișāl: Tráeme a Umm Rašīd, la & Sempronio: ... hechicera, astuta, sagaz en cuantas maldades \\
casamentera (al-jāṭiba), [...] conoce & hay. [...] A las duras peñas promoverá y provocará a lujuria, \\
a cada mujer honrada y golfa, y & si quiere [47]. \\
también a cada hermosa de Mișr y de & Calisto: ... Celestina sabia y buena maestra de estos negocios \\
al-Qāhira. [...] Mejor mediadora de & [88]. \\
amantes que la clavija de tijeras de & Celestina: ... Pocas vírgenes, a Dios gracias, has tú visto en esta \\
un sastre. Sabe también cómo tratar & ciudad que hayan abierto tienda a vender, de quien yo no \\
benévolamente los corazones de los & haya sido corredora de su primer hilado. En naciendo la \\
amantes y solo vende el sexo al & mochacha, la hago escribir en mi registro, y esto para que \\
gusto [22]. & yo sepa cuántas se me salen de la red [99]. \\
& Elicia: Oh Celestina, sabia, honrada y autorizada [289]. \\
\hline
\end{tabular}

Otro rasgo para destacar, el interés económico, sirve de aliciente para el desempeño de su oficio. Aunque la proyección artística de cada autor es distinta, el dinero es el justificante de la intervención. Umm Rašīd se preocupa más por el contento de los clientes que por ganar dinero. El médico recita: «Motiva al cliente, celosa del coito // ofreciéndole a cada hermosa delicada» [53]. Es persona de una sola palabra, referencia repetida en tres ocasiones: «ni discute el precio a pagar» $[22,23,53]$. Esta remuneración está claramente representada en el personaje de Celestina. Obtendrá además de dinero, una cadena de oro (causante de su tragedia final). No duda en acomodarse al concurso de las circunstancias para aumentar el lucro. La alcahueta pide con aire picaresco: «Por un manto que tú des a la vieja» [153]. A diferencia de Umm Rašīd, el interés económico constituye la ambición principal. La codicia es la que la arrastra a la muerte. En efecto, las relaciones sentimentales de sus clientes entre la clase alta solo le preocupan en la medida en que pueda sacar el mayor provecho posible. A este propósito, dice Celestina a Sempronio: «Dile [a Calisto] que cierre la boca y comience a abrir la bolsa» [66].

Aunque ambas viejas sean conocidas por su alta aptitud profesional, esto no quiere decir que no tengan sus propios vicios. Celestina, como su amiga Claudina, es muy aficionada al vino y lo consume en grandes cantidades. Celestina se consuela: «Yo que estoy sola porné cabe mí este jarro y taza. Que no es más mi vida de cuanto con ello hablo» [204]. Este rasgo no pertenecía solo a las proxenetas de la comedia y la poesía latina, sino también a las de la literatura árabe ${ }^{(26)}$. A diferencia de Celestina, el prototipo de la vieja bebedora no es un elemento

(25) El texto de Ibn Dāniyāl emplea la forma masculina como fenómeno genérico.

(26) Márquez Villanueva, F., Orígenes, p. 44. 
definidor de la imagen de Umm Rašīd. En ningún momento, la protagonista hace alarde de su amor al licor de Baco. Mencionado de paso, Umm Rašīd se muestra reacia de recoger los sobrantes de sus clientes: «ni aúna los posos del vino» [22] y en los encuentros de borrachera «pasa desapercibida como el chorreo de las velas» $[22]^{(27)}$.

\section{Otros rasgos característicos del tema celestinesco}

\subsection{Orgullo profesional}

El orgullo profesional es el tema más interesante de ambas obras. Pero en la Celestina existe una conciencia más profunda, puesto que describe con más ahínco la alta posición que ocupa dentro de la sociedad como otro profesional cualquiera. Celestina afirma: «Que todo me cuesta mi dinero y aun mi saber, que no lo he alcanzado holgando» [257]. Otra divergencia llamativa reside en que Celestina defiende, en primera persona, la dignidad de su actividad profesional. En cambio, los elogios de Umm Rašīd se producen por boca de otros protagonistas:

\begin{tabular}{|r|r|}
\hline Tayf al-Jayāl & Celestina \\
\hline El Emir Wișāl: Nunca viola un compromiso. [...] Ni se & Celestina: En esta ciudad nacida, en ella criada, \\
explaya en la casa de los clientes, es discreta en las & manteniendo honra, como todo el mundo sabe, \\
reuniones [...]. Concede préstamos y concierta citas & ¿conocida, pues, no soy? Quien no supiera mi \\
para los jueves y los lunes. Nunca regatea en el & nombre y mi casa, tenlo por extranjero [98-99]. \\
precio. Respeta sus citas incluso en la noche del & Celestina: Una sola soy en este limpio trato; en toda \\
destino (laylat al-qadr) [22-23]. & la ciudad, pocos tengo descontentos [131]. \\
El médico: Cuando imploraban la ayuda de la medianera & Celestina: Vivo de mi oficio como cada cual oficial \\
// corría tan rápido como el correo urgente [52]. & del suyo muy limpiamente [259]. \\
\hline
\end{tabular}

A pesar de este rasgo más auténtico e inseparable del carácter de la alcahueta española en toda la obra, Celestina muestra una íntima duplicidad: sobradamente segura de sí misma con manejo absoluto de las situaciones, pero agitada por visos de inseguridad interior [111-13]. En su camino hacia la casa de Melibea. A Celestina le entran los temores: «iOh dudosa y dura perplejidad! No sé cuál escoja por más sano. ¡En el osar, manifiesto peligro; en la cobardía, denostada pérdida!» [112]. A la inversa, Umm Rašīd, atrevida y desvergonzada, no conoce las vacilaciones de Celestina. Aunque la egipcia, tramposa en sus pretensiones, no titubea en prometer al emir Wișāl una novia hermosa acorde a su petición: «`Caramba! Son las cualidades de la novia que tengo. Pues ella tiene gracejo y es el objeto de quien es tímido» [25]. La profesionalidad de las alcahuetas queda bien consolidada, sobre todo por la alta consideración de sus herramientas de oficio para llevar a buen término sus empresas. Entre estas destrezas, destacan: religiosidad disimulada, hechicería, habilidad verbal, máxime del arte de seducción.

\subsection{Religiosidad y hechicería}

La religiosidad y las alusiones a la hechicería se encuentran en ambas obras. Ibn Dāniyāl no hace uso de la religiosidad puramente instrumental de las viejas de la literatura árabe, aquellas mujeres que deambulan por las calles con su cayado y su ostentoso rosario, como en las Mil y una noches $^{(28)}$. A Umm Rašĩd, en efecto, no le preocupa la identificación religiosa, puesto que abre las

(27) Este pasaje puede traducirse de otra forma, según el manuscrito consultado. En la versión inglesa de Kahle: «No frecuenta las tabernas para aprovecharse de los chorreos de las velas», en «The Arabic shadow play in Egypt», en Opera Minora, Leiden: Brill, 1956, pp. 302-306, p. 305. Versión seguida por Kotzamanidou, «The Spanish and Arabic ...», p. 97 y Márquez Villanueva, F., Orígenes, p. 45. Ambos establecen una similitud con el comportamiento de la alcahueta de Rodrigo de Reinosa en las Coplas de los comadres.

(28) Alf layla wa-layla. El Cairo: Būlāq, 1863, II, p. 133; III, p. 171 (Las mil y una noches, tr. J. Vernet, Barcelona: Planeta, 1968-75, I, p. 967; II, p. 915); Armistead, S. G. y J. Y. Monroe, J. Y., «Celestina's muslim sister», Celestinesca, 13, 2 (1989), 3-27, pp. 3-8. 
puertas de su negocio a todos sin discriminación alguna. En cambio, la pintura de Celestina pone de manifiesto su religiosidad popular para una favorable solución de sus misiones:

\begin{tabular}{|l|c|}
\hline \multicolumn{1}{|c|}{ Tayf al-Jayäl } & \multicolumn{1}{c|}{ Celestina } \\
\hline El médico: ¡Cuántas veces ha armonizado los & Sempronio: ... cuando va a la iglesia con sus cuentas en la \\
corazones, sin discriminar entre musulmanes y & mano... Lo que en sus cuentas reza es los virgos que \\
judíos! [53]. & tiene a cargo y cuántos enamorados hay en la ciudad y \\
& cuántas mozas tiene encomendadas y qué despenseros \\
& le dan ración y cuál mejor [201-2]. \\
\hline
\end{tabular}

En cuanto a las artes diabólicas, en el modelo celestinesco tópico es la estrecha relación entre alcahuetería y hechicería ${ }^{(29)}$. La literatura árabe señala que el hombre llegó al conocimiento del arte de la alcahuetería por obra de Satanás ${ }^{(30)}$. Varias alusiones de ambos textos indican la ayuda prestada por este ángel rebelde. La obra egipcia alude al poder de Umm Rašīd sobre el demonio con humor. En términos parecidos, Rojas recurre a un símil jurídico, cliéntula, en el que presenta a la alcahueta no como sirviente del diablo sino, todo lo contrario, a éste como su fiel vasallo. Véase lo siguiente:

\begin{tabular}{|c|c|}
\hline Tayf al-Jayāl & \multicolumn{1}{c|}{ Celestina } \\
\hline $\begin{array}{c}\text { El emir Wișāl: Iblís besa el suelo ante ella a diario, } \\
\text { y es el único que la despierta de su sueño [23]. }\end{array}$ & $\begin{array}{c}\text { Celestina: Conjúrote [...] capitán soberbio de los } \\
\text { condenados ángeles... Yo Celestina, tu más conocida } \\
\text { cliéntula" [108-109]. }\end{array}$ \\
\hline
\end{tabular}

Aparte de esta coincidencia con Celestina, hay también una diferencia clara. Celestina lo invoca y le pide ayuda para lograr que Melibea acepte el amor de Calisto. Vale decir que el elemento mágico es revelador en el entramado narrativo. Para realizar sus rituales, Pármeno afirma: «pintaba figuras, decía palabras en tierra» [61]. No obstante, en la obra egipcia no se hace mención de ningún comportamiento de posibles prácticas mágicas.

\subsection{Habilidad verbal}

Sí Ibn Dāniyāl no ahonda en el recurso de lo demoniaco en su obra, es porque saca más partido del legado precedente. Es el caso de la magia manipuladora del lenguaje y el arte de seducción, empleada con ingenio y sagacidad ${ }^{(31)}$. Ibn Dāniyāl tomó como norte el adaptar la maqāma 'sesiones/cuadros novelescos' al teatro de sombras, prueba de fuego de su maestría literaria. Utiliza, en efecto, la prosa rimada y la representación binaria de los personajes principales. Así pues, el texto de Ibn Dāniyāl viene a ser una singular combinación entre el árabe clásico y el dialecto egipcio. Respeta particularmente el precepto del decoro, amoldamiento del lenguaje al estamento social de los marginados. Por ello, la exuberancia verbal de Umm Rašīd oscila entre imprecaciones, juramentos, refranes, frases hechas, propios de la cultura popular, pero también parlamentos exquisitos a base de poesía amatoria. Al involucrar al emir Wișāl en un matrimonio nefasto, la casamentera le dice وقع الفأس في الراس , esto es, «Lo hecho, hecho está» [40]. En otro lenguaje más colorido, dice: «Tengo una moza que se

(29) Russell, P. E., «La magia, tema integral de la Tragicomedia de Calisto y Melibea» en Homenaje a Dámaso Alonso, III, Madrid: Universidad Complutense, 1963, pp. 337-54 (aparece posteriormente en Temas de «La Celestina» y otros estudios del «Cid» al «Quijote», Barcelona: Ariel, 1978, 243-76.

(30) Al-Tīfāšī, Nuzhat al-albāb, pp. $84-5$ (tr. esp. Esparcimiento de corazones, pp. 71-2); Shafik, A., «La mujer...», p. 211

(31) Márquez Villanueva, F., Orígenes, p. 30. 
parece al sol resplandeciente» [26]. Además, sabe encender el imaginario erótico del emir Wișāl celebrando con sensualidad descriptiva el cuerpo de la novia:

¡Qué belleza! Como si la pluma del Creador maravillosamente

la dibujase, y al verla, quedan perplejos los calígrafos [25].

En cuanto a la lengua de la Celestina es afinadamente artificiosa, fruto de una cuidadosa labor retórica, repleta de erudición antigua, pero ni la clase alta ni la baja, submundo de prostitutas encabezado por Celestina, es ajena a la expresión vulgar. Desde su aparición (capítulo I) hasta su muerte (capítulo XII), Celestina despliega su capacidad de manipulación, corruptora elocuencia para la satisfacción de deseos sexuales (caso de Calisto y Melibea), habilidad para la mentira a través de promesas de ganancias compartidas (caso de Sempronio), agudeza de sus palabras, sarta de refranes. Todo esto con el fin de convencer y ganar la voluntad de sus interlocutores. Para seducir a Melibea, Celestina ensalza la belleza de la joven: «... en balde pintase Dios unos gestos más perfetos que otros, más dotados de gracias, más hermosas facciones, sino para hacerlos almacén de virtudes» [125].

\section{Crítica social}

Țayf al-Jayāl de Ibn Dāniyāl y la Tragicomedia de Rojas se elaboran en un momento histórico que corresponde a finales de los siglos XIII (egipcia) y XV (española), respectivamente. Las narraciones de dichos creadores carecerían de pleno sentido si se construyesen a espaldas de las coordenadas de su marco histórico-social. En la obra de Ibn Dāniyāl, Umm Rašīd refleja un protagonismo inusual respecto a los otros héroes. Haciendo uso de la tradición carnavalesca, el autor le presta su voz para poder criticar, en tono libre y jocoso, a los grupos dominantes, militares mamelucos desconectados de su propia sociedad; a las autoridades religiosas poco convincentes ${ }^{(32)}$; a los intrusos en su mundillo erótico, como el emir Wișāl (lit. 'unión amorosa'), burlándose de sus glorias sexuales pasadas y haciéndole casar con una vieja consumada. En la escena de la firma de las actas de boda, Ibn Dāniyāl pincela el retrato de la tercera, donde se disuelve la frontera entre el oficio de casamentera y alcahueta. Para Rojas, Celestina fomenta el enfrentamiento entre criados y señores, insistiendo en la violación de código social al uso ${ }^{(33)}$. La alcahueta incita a Pármeno a mirar con otros ojos su relación amocriado vasallática con Calisto. En el proceso de acoso y derribo a la fidelidad de Pármeno, Celestina le llama la atención sobre el egoísmo y los abusos de su amo, invitándole a unirse con los de su clase para conseguir los mayores beneficios. En otra escena con Areúsa, moza independiente y libre con respecto a los negocios de la alcahueta, Celestina muestra su total acuerdo con la intrépida proclama de la joven, que prefiere vivir como libre meretriz a ser criada subyugada a los antojos de las señoras de la clase alta. Obsérvense los siguientes parlamentos de ambas obras:

(32) Sobre la burla de los ulemas de la época, véase Shafik, A., «El pícaro en la literatura árabe: ${ }^{\complement} A \hat{y} \bar{\imath}$ wa Garīb de Ibn Dāniyāl», Miscelánea de Estudios Árabes y Hebraicos, 68 (2019), 361-389, pp.379-82.

(33) Ladero Quesada, M. A., «Aristócratas y marginales: aspectos de la sociedad castellana en La Celestina», en Estudios sobre la Celestina, ed. S. López-Ríos, Madrid: Ediciones Istmo, 2001, pp. 213-240. 


\begin{tabular}{|c|c|c|}
\hline & Tayf al-Jayāl & Celestina \\
\hline $\begin{array}{l}\text { Clase alta } \\
\text { (los señores) }\end{array}$ & & $\begin{array}{l}\text { Celestina: (Los señores) desechan la } \\
\text { sustancia de sus sirvientes con huecos } \\
\text { y vanos prometimientos. Como la } \\
\text { sanguijuela saca la sangre [....], Estos } \\
\text { señores deste tiempo más aman a sí } \\
\text { mismo que a los suyos [73]. }\end{array}$ \\
\hline $\begin{array}{l}\text { Clase alta } \\
\text { (las señoras) }\end{array}$ & & $\begin{array}{l}\text { Areúsa: ... he querido más vivir en mi } \\
\text { pequeña casa, esenta y señora, que } \\
\text { no en sus ricos palacios, sojuzgada y } \\
\text { cativa [213]. } \\
\text { Celestina: En tu seso has estado; bien } \\
\text { sabes lo que haces [214]. }\end{array}$ \\
\hline $\begin{array}{l}\text { Autoridad } \\
\text { (gubernativa) }\end{array}$ & $\begin{array}{l}\text { Tayf al-Jayāl: [Deja de burlarte del príncipe]; } \\
\text { cállate para que no te oiga y te dé una bofetada. } \\
\text { Hoy está de mal humor. Es más fuerte que } \\
\text { Faraón: amenazando y sacando las uñas, } \\
\text { mostrándose despótico e imperioso, } \\
\text { encarcelando y poniendo en libertad; y con la } \\
\text { mano sujetando el bastón de mando [23]. } \\
\text { Umm Rašīd: ¡Cómo! ¡Cómo! ¡Mala landre te } \\
\text { coma! Se ha olvidado de los descampados por } \\
\text { vivir en el palacio [23]. } \\
\text { (El emir Wișāl como si no hubiera escuchado } \\
\text { nada) [25]. }\end{array}$ & \\
\hline $\begin{array}{l}\text { Autoridad } \\
\text { (religiosa) }\end{array}$ & $\begin{array}{c}\text { Umm Rašĩd: Es cierto, hijo mío, si ambas partes } \\
\text { están de acuerdo, hay que llamar al tutor y al } \\
\text { juez, y, si tú quieres, sin juez (se burla de las } \\
\text { costumbres, aludiendo a la alcahuetería) [26]. }\end{array}$ & \\
\hline
\end{tabular}

\section{Conclusiones}

Al escribir Ibn Dāniyāl su Tayf al-Jayāl recupera alegremente la larga tradición literaria de la vieja escuela árabe, rescatándola de una repetición trillada y monótona. El caso del modelo hispánico se caracteriza por una naturaleza especial por la confluencia de elementos clásicos, orientales, medievales y petrarquescos. Con el mismo espíritu renovador, Rojas reaflora la alcahueta literaria hispano-oriental, tan sometida a un estereotipo trivial, convirtiéndola en personaje artístico de gran dimensión universal.

Como se ha visto, ambas protagonistas comparten unos rasgos caracterizadores del modelo celestinesco: antiguos recuerdos, oficios, profesionalidad, recompensa material, inclinaciones sexuales, y sobre todo el poder de la palabra, principal aliado y rasgo implícito en su actividad, con el cual embaucan a los demás personajes (el emir Wișāl en Tayf, y los criados en la Celestina), zurcen las voluntades y hacen mella en la virtud (el caso de Melibea). Además, las dos medianeras manifiestan una supremacía dialéctica decisiva sobre todos los personajes que las circundan. No obstante, el poder de seducción de Umm Rašīd se ve más reducido debido a su limitada aparición en la obra. De hecho, solo puede tender sus redes ante el novio, el emir Wișāl.

Hay algunas diferencias entre Umm Rašīd y Celestina. Ni la enofilia, ni la hechicería poseen la misma función caracterizadora del personaje. Ibn Dāniyāl emplea estos rasgos exclusivamente en clave jocosa, pues no saca ningún fruto de ello ni aportan nada al desenlace de la obra. Tampoco existe un interés mesurado respecto al dinero. Su alusión solo le sirve para acercarse a los cánones del paradigma celestinesco. Lo mismo se puede decir acerca de la religiosidad de índole popular, brilla por su completa ausencia en la obra egipcia. Ibn Dāniyāl 
decidió arrinconar la dimensión religiosa, hecho que se podrá entender mejor en la época mameluca, conocida mayormente por la tolerancia religiosa.

Otra diferencia importante que hay que resaltar: En la obra egipcia, se presta especial atención a la dicotomía carnavalesca contradictoria dividida en mundo popular / oficial, príncipes y villanos. De hecho, los dardos de Umm Rašīd, personaje popular y carnavalesco, van dirigidos principalmente contra los grupos dominantes, los poderosos de la tierra de su momento (militares, imanes), incluso contra las convenciones sociales regidas por el mundo oficial (institución del matrimonio), En cambio, Celestina debe plantar cara continuamente a la voluntad individual y la psicología de los demás personajes (oposición, resistencia, recelos, pudor, honra), con el hábil manejo de la palabra. Por eso, la estrategia de Umm Rašīd no se asienta solo en la pericia verbal, sino también en el engaño, en las obras (organizar y publicar una boda con mujer fea).

Para cerrar este colofón, habrá que formular una última pregunta, ¿por qué el personaje de Umm Rašīd no ha logrado el mismo protagonismo que Celestina, por lo menos en la tradición literaria árabe, habida cuenta de su capacidad de aunar entre el oficio de casamentera y alcahueta?

A nuestro parecer, habrá que situar el personaje de Umm Rašīd en el contexto global del teatro de sombras de Ibn Dāniyāl, teatro del pueblo, reflejo de la vida y espejo de la sociedad de su momento, donde prevalece lo colectivo por encima de una personalidad dominante. En cambio, la irresistible presencia de Celestina y la perfecta articulación de sus cualidades, síntesis de varias tradiciones, la llevaron a arrebatar el título de la obra y a convertirse en un modelo a la altura del mito. 